\title{
Corporate Systems of the Knowledge Management in the Practices of Integrated Companies
}

\author{
Tatiana Vladimirovna Ponomarenko \\ Dina Ziyatdinovna Khaertdinova
}

National University of mineral resources, 199106, 21 line, 2, Saint-Petersburg, Russia

Email: stv_mail@mail.ru

Doi:10.5901/mjss.2015.v6n3s3p203

\begin{abstract}
Intellectual capital is becoming the most important resource, which forms the key competitive advantage of companies, especially of big integrated companies in the fast developing environment. Accordingly, intracompany management of the intellectual capital and its elements should be based on justification of the estimation methods, reproduction lines, and efficiency of its application in the company operations. Immaturity of the theoretic apparatus and methodological problems of the intellectual capital management, which are related to the understudied specific of the capital, require investigation of evaluation, choice of means and methods to transform intellectual resources into assets, reproduction, development, and efficient use of the intellectual capital. Human capital is assessed by the extent of the stored and efficiently practiced knowledge, and holds the most important place in the intellectual capital. The goal is to estimate formation and efficient use of the corporate systems of knowledge management in integrated oil companies based on the personalization strategy. Knowledge management strategies have been analyzed and it has been proved that the personalization strategy is a dominant strategy of Russian companies. It has been justified that efficient use of the intellectual capital is achieved through the corporate systems of knowledge management. Knowledge management practices of the biggest Russian vertically integrated oil companies have been studied and lines of development of the corporate systems of knowledge management have been proposed.
\end{abstract}

Keywords: knowledge, intellectual capital, importance, knowledge management system, intellectual model, oil companies.

\section{Introduction}

In the information society, intellectual capital is considered the most important resource, which enables increase in the competitive ability of companies through the active innovative activities. In some countries, the amounts invested into the intellectual capital exceed the investments into physical and financial capital (OECD, 2007; Zeghal \& Maaloul, 2010). The most important element of the intellectual capital is the human capital, and reproduction and efficient use of this capital should ensure the growth of the corporate value.

Even developed countries are far from solution of such issues as immaturity of the methodological apparatus, methodological and methodical problems of the intellectual capital management, including accounting and evaluation methods, choice of the methods for transformation of intellectual resources into assets, reproduction, development, and efficient use of the intellectual capital

The goal is to estimate formation and efficient use of the corporate systems of knowledge management in integrated oil companies based on the personalization strategy.

The research methodology: based on the analyzed knowledge management strategies of Russian oil companies, it has been proved that personalization strategy is the dominant one. The process of transformation of the tacit knowledge into the explicit knowledge in the corporate systems of knowledge management has been studied. Knowledge management practices of the biggest vertically integrated Russian oil companies have been analyzed. Their advantages and disadvantages have been identified and lines of development of the corporate knowledge management systems have been proposed. 


\section{Literature Review}

\subsection{Terms}

Intellectual capital (lat. intellectus - sense, reflective faculty, capitalis - main, principal) is an aggregate of intellectual resources, abilities, and skills used by a company for the profit earning purposes. Currently, intellectual capital is understood as the transferable knowledge owned by an organization (Bontis, 1999); the knowledge, which can be converted into value (Edvinsson \& Malone, 1997). Zeghal and Maloul gave broad definition of the term (Zeghal \& Maaloul, 2010). In their opinion, intellectual capital is a body of all knowledge, which can be used by a company in the process of the added value formation. The managerial aspect is emphasized in the definition of the intellectual capital as "an aspect based on the connections, structured knowledge and capabilities with the potential for development and delivery of the value" (Daum, 2005). Corporate intellectual capital is a qualification, experience, motivation of the employees, who are able to create added value and who provide the competitive advantages of the organization.

The term intellectual capital can be defined in different ways depending on the considered aspect. Economic interpretation in a general sense is focused on the demonstration of the form of capitalization of the intellectual facilities of the intellectual capital; from the marketing and management point of view, intellectual capital is understood as patents, management skills, processes, technologies, experience, relations with consumers and knowledge about them, which are not always documented. Accounting interprets the intellectual capital as an aggregate of intangible assets of an organization, which are available for assessment and management because they are indicated in the accounting documents.

\subsection{Intellectual capital and knowledge management}

Intellectual capital, as well as the physical capital, is earned by investment of various resources and it can lose its value and depreciate. The main difference between the intellectual capital and the physical capital is the non-material nature and peculiar characteristics. Herewith, it is important to note the measurement difficulty, estimation in both monetary and non-monetary forms, the potential gain in value afterwards, and the lack of full scope of the proprietary rights of the organization to the intellectual capital. Structurally, intellectual capital is an aggregate of human, organizational, and customer (consumer) capitals (Ruus et al., 2008; Stewart, 1999; Brooking, 2001). An important characteristic of intellectual capital is the possible synergistic effect in the system trough the components interaction.

The principal goal of the intellectual capital management is intellectual support of the corporate business processes, constant development and increase in the value of the intellectual assets. The mechanism of the goal implementation is creation and development of the system of intracompany management of the intellectual capital. Modern production requires high level of qualification, knowledge, skills, experience, and competence of the employees who become the human capital. Human capital is a core component of the intellectual capital and the principal source for adding value because it is a foundation of the corporate knowledge capital. Other components of the intellectual capital are the derivative results of the human capital, or the human factor impact has a determining importance for them. Therefore, it is necessary to look for methods, which would enable efficient management of the corporate intellectual capital aiming the increase in the intellectual capital value, profit maximization, and efficient application of human resources (Zeghal, 2000).

Increase in the value of the intellectual capital can be achieved in a number of different ways, one of which are the knowledge management systems followed by the strengthening of the competitive ability and increase in the market value of the company. Knowledge management is a continuous process oriented to the efficient creation, accumulation, and application of the knowledge in the company. This scientific field is young enough. It has been developing since one of the first works on knowledge management was published and the first scientific conference related to the subject was held in 1987.

The publications of the reports of the Scandia Company on the factors determining the true value of the company in 1993 and 1994 were a breakthrough in the formation of the intellectual capital concept. The company commenced to publish supplements to the annual financial report «Visualizing Intellectual Capital in Scandia» in 1994 (Edvinsson \& Malone, 1994). The main formation principles and essence of the methods of Scandia Navigator (Edvinsson \& Malone, 1997) contains new methods of social and economic measurements. When the authors compare the intellectual capitals with the roots of the company, which are hidden with the development factors, they define the value of the intellectual capital as the differences between the shareholder value of the company and value of its net assets.

Tobin puts a similar approach to the definition of the value of the intellectual capital into his formula, where 
intellectual capital is the ratio between the market or fundamental value of the company and the replacement price of its fixed assets. Application of the coefficient has the following principle: if the value of the company significantly exceeds its tangible assets, it evidences the higher value of its intangible assets. Tobin's $Q$ ratio is high and keeps growing for efficient, growing and developing companies. If Tobin's $Q$ ratio is less than one, it evidences problems of the company, inadequate estimation, and low competitive ability.

Knowledge management is interpreted in the contemporary literature as a new management function consisting in the "regular and targeted formulation, renovation, and application of the knowledge in order to maximize the company efficiency and profit from the knowledge-based assets" (Milner et al., 2006).

\section{Methods}

Amongst various interpretations of the term knowledge, we are going to apply the interpretation of the European Guide to Good Practice in Knowledge Management (European Guide..., 2004) for the purposes of the study: "Knowledge is a combination of data and information together with the opinion, skills and experience of an expert resulting in valuable assets, which can assist in making of decisions."

All the knowledge of organizations is divided into explicit and tacit. Explicit (formalized) knowledge is knowledge, which exists in the form of documents, reports, etc. Tacit (unformalized) knowledge is owned by the employees holding it. There are various opinions on the correlation between the explicit and tacit knowledge in different organizations. The results of the research on the knowledge structure of the presented group of US companies performed by the Delphi Group in 2000 revealed that a little more than $50 \%$ of knowledge is explicit, and the rest is tacit (Tuzovski et al., 2005). Some expert evaluations show that correlation between the explicit and tacit knowledge is 20 to 80 on the average. Thus, the main goal of the knowledge management system is reduced to the enhancement of the efficiency of the use of corporate intellectual resources trough the transformation of the tacit knowledge into explicit.

There is a continuous exchange and transformation between the explicit and tacit knowledge (Nonaka \& Takeuchi, 2003). This circular process of the knowledge transformation within one form or in transitions from one form to another includes:

Communalization (tacit to tacit) includes formation and transfer of tacit knowledge in the collective forms (discussions, seminars, orders, etc.). Herewith, this process does not include creation of the evident knowledge in the most cases.

Alienation (tacit to explicit) is performed through conceptualizing the new knowledge, extracting and revealing the knowledge, and, finally, formulating and recording it in one form or another as a result of discussions, seminars, brainstorming, etc.

Combination (explicit to explicit) is performed in the process of sharing the explicit knowledge by e-mail, in the course of preparing reviews and consolidated reports. The evident knowledge grows due to appending shared databases, classification and systematization of files and documents, etc.

Assimilation (explicit to tacit) is performed in the process of reading documents from databases, magazines, and books. This results in the assimilation of the knowledge, which has been created by others (formation of new tacit knowledge at the cognizer), and, maybe, in the development of new knowledge as a result of mental activity in the process of perception.

According to Romer (Romer, 1995): "Knowledge is the only unlimited resource, the one asset that grows with use." Ideas generate new ideas, and the transferred knowledge remains with those who share this knowledge. Thus, the American Productivity \& Quality Center (APQC. Knowledge Management ...2013) considers the knowledge management as an aggregate of strategies and processes focused on the exposure, acquisition, sharing, use, control, and exchange of the knowledge required to provide competitive ability of the business.

Two strategies of the knowledge management in companies are identified: one strategy is focused on the knowledge coding and the other is focused on the knowledge personalization.

The coding strategy is based on the wide use of IT-tools for the data search and support of electronic databases, which enable accumulation of the intellectual capital. The advantages are cost reduction through the economies of scale on the knowledge reuse by big vertically integrated companies and enhancement in the value of the intellectual capital (intensive exchange of experience, decreasing in the number of repeated mistakes, etc.). A disadvantage of the strategy is a disincentive to the innovative activity and creativity of employees.

Knowledge personalization strategy is much more oriented to the development of employees' creativity and acceleration of the knowledge exchange process. The focus is on the development of social interaction between the project teams and individual employees, which enables finding the problem solutions through joint efforts. 
Results of the expert survey performed by the Institute of Psychology of the Russian Academy of Science in 2013 are of great interest. This survey is focused on finding the knowledge management tools, which are used by domestic companies. Experts of 20 Moscow organizations in the energy, production, and wholesales field participated in the survey. According to the survey results, the most widely used knowledge management tools are corporate portals (over $95 \%$ of the respondents), internal advisers and coaches (over $80 \%$ of the respondents), counseling systems (over 70\%), as well as remote education systems (over 50\%). The obtained results demonstrate the latest tendency of Russian companies to dropping the knowledge coding strategy in favor of personalization as well as attempts to combine both strategies.

The main reasons of the need to use knowledge management systems by big organizations are as follows:

1. it takes a lot of time for the employees of companies to find the required information;

2. the knowledge and skills of the most qualified employees are not used in full because they are not coded;

3. important information can be lost in the huge amount of data, access to which can be hindered;

4. the high cost of systematic errors related to the lack of the required information and ineffective transfer of the knowledge.

\section{Results}

\subsection{Knowledge management systems in foreign oil companies}

Foreign experience of the practical use of knowledge management systems is over 20 years. Results of the investigations performed by the American Productivity and Quality Center (APQC) show that, for example, transnational corporations (TNC) receive two dollars per every dollar invested into the corporate knowledge management (APQC. Knowledge Management..., 2013). According to the results of the investigations of the Global Industry Analysis Company, the operating profit on the market of the knowledge management service in 2012 amounted to over USD 157 billion (Global Industry Analysis, 2008).

Goals and results of the implementation of the knowledge management systems into foreign oil and gas TNC confirm the practical relevance of knowledge management (Table 1).

Table 1. Results of the knowledge management systems implementation (as exemplified by foreign TNC of the oil and gas sector) (Brazhnikova, 2012)

\begin{tabular}{|c|l|l|}
\hline TNC & $\begin{array}{l}\text { Goals of the knowledge management system } \\
\text { implementation }\end{array}$ & $\begin{array}{l}\text { Results and efficiency of the knowledge management system } \\
\text { implementation }\end{array}$ \\
\hline Chevron Texaco & $\begin{array}{l}\text { Reduction of the operating costs } \\
\text { Improvement of the operations }\end{array}$ & $\begin{array}{l}4^{\text {th }} \text { place by capitalization in the world. } \\
\text { Increase in performance by 30\% } \\
\text { Reduction of the operation costs by USD 1 billion } \\
\text { Reduction of the green-field development costs by 12-20\% }\end{array}$ \\
\hline Shell & $\begin{array}{l}\text { Reduction of time required for the search of } \\
\text { necessary information. Informational } \\
\text { independence of the company. }\end{array}$ & $\begin{array}{l}\text { Providing access to the necessary knowledge and } \\
\text { experience to all employees, which resulted in the annual } \\
\text { savings of USD 200 million. }\end{array}$ \\
\hline British Petroleum & $\begin{array}{l}\text { Development of advantages through own } \\
\text { "know-now" }\end{array}$ & $\begin{array}{l}\text { Annual saving of USD 260 million through the duplication of } \\
\text { the knowledge exchange system }\end{array}$ \\
\hline Schlumberger & $\begin{array}{l}\text { Increase in the speed of the search of solutions } \\
\text { for technological problems of the company } \\
\text { customers. }\end{array}$ & $\begin{array}{l}\text { Annualized saving of over USD 150 million. } \\
\text { Cutting time required for the upgrading of the production } \\
\text { equipment by 75\% }\end{array}$ \\
\hline
\end{tabular}

Russian oil and gas companies express strong interest in the knowledge management. Cutting costs for the oil and gas production, reproducing the base of minerals and raw materials, maintaining the position on the world energy markets require implementation of innovative mechanisms, including mechanisms of efficient knowledge management.

\subsection{Knowledge management system: approaches, content, goals}

Knowledge management is management of knowledge-related processes or management of the processes of knowledge handling. There are two approaches to knowledge management, which are essentially different (McElroy, 2003).

Approach of the first generation assumes that an enterprise already owns precious knowledge, i.e. it has already 
been created. Therefore, it is necessary to record, code, and distribute the knowledge. Consequently, in this case the goal is not the improvement of the process of creation (development) of knowledge, but just its practical application.

The second generation of knowledge management assumes that knowledge is not prepared. It is constantly created in the process of knowledge processing. Application of the knowledge in business processes verifies the knowledge, reveals new problems, and forms demand for the new knowledge and its satisfaction.

The main goals of a knowledge management system are:

- knowledge acquisition, i.e. application of the available knowledge and adaptation of the knowledge for the corporate needs (for example, through the open trade mode, attraction of foreign investments, and conclusion of license agreements). Obtaining knowledge through the research and development and usage of the local knowledge is also assumed;

- knowledge assimilation (for example, development of the abilities for training of the employees during the lifetime and development of the higher education system, especially, in the field of science and technology);

- knowledge transfer, i.e. competition-based application of new information and telecommunication technologies, corresponding statutory regulation, and providing access to information resources.

At building knowledge management systems, it is necessary to take into consideration that this is not just an aggregate of knowledge and competence of employees, because the development, use, cooperation, and collective work manifest the synergistic effect, which involves improvement of the efficiency of individual solutions.

Creation of new corporate knowledge requires participation of the employees who play different roles and occupy various positions in the company hierarchy. The value of the contribution of every employee, notwithstanding of the category of the employee, is mainly determined by the importance of the provided information, his/her working capabilities and skills with regard to the knowledge and teamwork. A team creating knowledge must include practitioners, organizers, and ideologists of the knowledge (Nonaka \& Takeuchi, 2003). Knowledge practitioners are, in most cases, average employees and first-line managers. Organizers are middle managers, and ideologists are executive managers.

\subsection{Knowledge management systems in Russian oil companies}

Every company determines its methods and selects its tools of knowledge management. The knowledge management practice has been analyzed on the example of the biggest Russian vertically integrated oil companies, such as JSC Tatneft, JSC NK Rosneft, JSC Oil Company "Lukoil", JSC Gazpromneft. The information sources are corporate reports of the companies represented on their official websites (http://www.tatneft.ru, http://www.rosneft.ru, http://www.lukoil.ru, http://www.gazprom-neft.ru).

The key performance indicators of the companies are presented in Table 1, at Figures 1-2.

Table 1. The key performance indicators of Russian oil companies for 2011-2013

\begin{tabular}{|c|c|c|c|c|c|c|c|c|c|c|c|c|}
\hline \multirow{3}{*}{ Name of the indicator } & \multicolumn{12}{|c|}{ Company name } \\
\hline & \multicolumn{3}{|c|}{ JSC NK Rosneft } & \multicolumn{3}{|c|}{ JSC Lukoil } & \multicolumn{3}{|c|}{ JSC Gaspromneft } & \multicolumn{3}{|c|}{ JSC Tatneft } \\
\hline & 2011 & 2012 & 2013 & 2011 & 2012 & 2013 & 2011 & 2012 & 2013 & 2011 & 2012 & 2013 \\
\hline Oil extraction, mln. tons. & 118.7 & 122.0 & 206.9 & 90.9 & 89.9 & 90.8 & 57.3 & 59.7 & 62.3 & 25.9 & 26.0 & 26.1 \\
\hline Sales revenue, bln. rubles & 2,718 & 3,089 & 4,694 & 4,277 & 4,453 & $4,526.4$ & 1,030 & 1,233 & 1,268 & 319 & 345 & 364 \\
\hline Net profit, bln. rubles & 335 & 365 & 551 & 242.6 & 217.8 & 210.0 & 160 & 176 & 178 & 55 & 67 & 64 \\
\hline Additional capital, bln. ubles & 386 & 385 & 477 & 154 & 152 & 146 & 10 & 16 & 19 & 0.009 & 0.010 & 0.031 \\
\hline $\begin{array}{l}\text { Average number or } \\
\text { employees, ths. persons }\end{array}$ & 160.8 & 166.1 & 228.0 & 120.3 & 112.0 & 109.6 & 58.9 & 54.8 & 56.0 & 21.0 & 21.1 & 20.8 \\
\hline
\end{tabular}




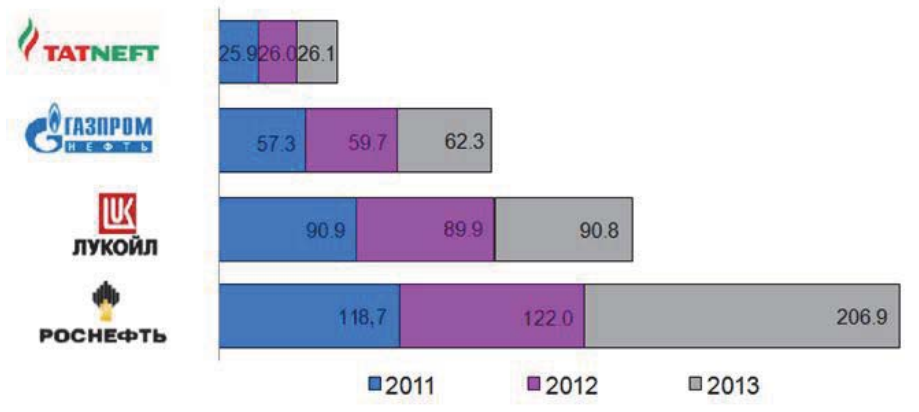

Figure 1. Oil production by Russian oil companies, million tons.

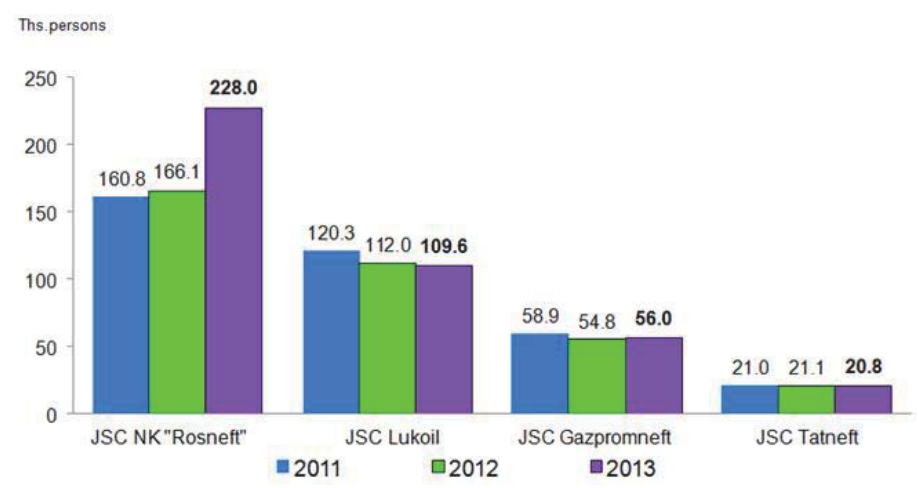

Figure 2. Average number of employees of Russian oil companies, ths. personsJ SC Tatneft

Open innovations are oriented to the search of knowledge with the involvement of the external participants (in contrast to the closed innovations, which use only internal resources of the company) and result in extension of the innovative capacity of the company. Any innovations within the holding are open, because several structural units are involved into the implementation. However, the holding interests are characterized by the entity, consequently, innovations in such a system, which does not involve external parties, will be considered as open and closed innovations.

One of the tools applied by the Tatneft company for knowledge management is the technology, which relies on open innovations - crowdsourcing. Crowdsourcing is a technology of knowledge systematization, search for mechanisms of using and development of mechanisms of implementation. The crowdsourcing technology is easy-to-use and does not require solid investments and fundamental changes in personnel arrangements and principal business processes of the company. The crowdsourcing system is an interactive and multifunctional platform put on the Internet, which enables arrangement of the joint activity of the company employees and knowledge exchange in the communication process. Crowdsourcing enables generation of new ideas and search for qualified experts, active, and talented leaders and innovators.

"Auction of Business Ideas" (http://bank.ec-univer.ru) is a corporate crowdsourcing project of JSC Tatneft within the specialized Internet-platform (since May, 2013). The main goal of the project is generation of ideas by many persons and search for alternative problem solutions. The operating algorithm of the "Auction of Business Ideas" is formed as follows: identification of the problem, evaluation of the problem urgency, collective generation of ideas, selection of the best idea, and manufacturing application of the idea. As a result, the company may find a solution of the problem with due consideration of many ideas of the innovators and crowdsourcers may obtain a reward. Project implementation mechanism includes 3 information centers: "Bank of Problems", "Bank of Ideas" and "Bank of Knowledge."

After collection of innovative ideas, experts estimate these ideas and form the rating of the best solutions, which then come on the auction. Originators of the problem choose an idea and determine the author's reward based on the rating of the idea. Funding is provided by the Fund of Costs Savings of JSC Tatneft, which has been functioning since 2005 as a part of the Program of Improvement of the Economic Management and Operating Cost Reduction. This fund is annual established in the amount of 1 billion rubles (at the expense of over-plan oil extraction, gain in the volume of product sales, business measures for the cost optimization and efficiency upgrading, etc.). 
In order to expand the territorial borders and the number of active innovators, the company in 2014 attempted to involve external innovators to the "Auction of Business Ideas", but this process did not have the expected effect and was temporary suspended.

The "Auction of Business Ideas" for 2013-2014 in JSC Tatneft has the following statistics: over 12 thousand registered users, over 14 thousand identified problems, about 10 thousands of which have been published, over 65 thousand published ideas. Thus, we can make a conclusion on the high level of interest in the employees and qualitative work of experts. Innovative crowdsourcing development already has sufficient effect, which results in the production efficiency growth and innovative development of the employees and company.

Despite certain difficulties related to the implementation of crowdsourcing platforms, these platforms are able to solve the problem of management of one of the components of the intellectual capital - human knowledge. This technology enables both collective generation of ideas related to the challenging issues, and accumulation and distribution of the best practices for the following use.

Currently, many companies have realized how necessary it is to accumulate knowledge and best practices for the purposes of the efficient diffusion. In 2013, JSC Tatneft launched the IT-project "Center of Excellence of JSC Tatneft" (CE) (http://intranet.tn/cpo) in the corporate network, which has been developed and created in order to accumulate and diffuse new knowledge and the best practices. This project uses the crowdsourcing technology as a basis for its functioning. All employees of the company can place their materials on the platform. This resource enables employees to access the joint base of knowledge accumulated both inside the company and during participation of the company employees in external events -business trips, business meetings, conferences, etc.

JSC NK "Rosneft"

In 2006, Rosneft launched the "Knowledge Management System" project. The purpose for the development of this system is arrangement of efficient knowledge management through formalization and automation of the corresponding processes and development of knowledge management methodology in the company. Herewith, the sources of the revelation and obtaining of the knowledge can be both internal and external.

The knowledge management system consists of the following main components:

- planning and management of research and development works and projects (planning of the new knowledge acquisition);

- project areas (execution of work on obtaining new knowledge within the corresponding projects);

- $\quad$ knowledge exchange (elicitation of the knowledge within experience exchange in expert communities);

- information repository (storage and diffusion of the new obtained knowledge).

The "Knowledge Exchange" section holds the key place in the structure of the system because it contains modules, which enable derivation of explicit and tacit knowledge of the company employees. The section includes three principal modules: the bank of innovations (meant for collection and processing of innovative proposals of the company employees), the bank of technologies (tools for collection, storage and diffusion of the knowledge on the technologies proposed on the market, practices of application of the technologies in "Rosneft" and other oil companies of the world), the expert system (for arrangement of structured and documented knowledge exchange) (Figure 3).

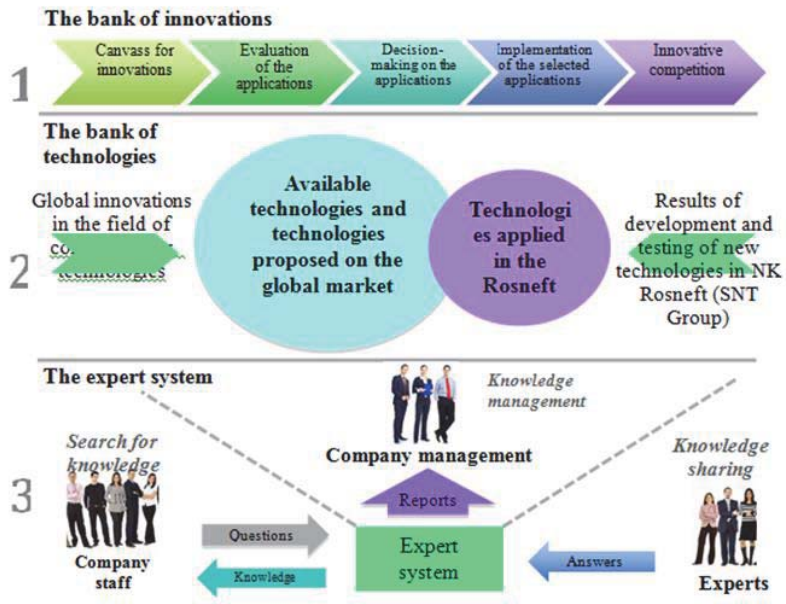

Figure 3. Modules of the "Knowledge Exchange" section 
All the components of the knowledge management system are closely connected and are parts of one cycle of knowledge management.

\subsection{JSC Lukoil}

The management of the Lukoil company believes that knowledge management is one of the priority projects related to the development of the innovative processes, scientific and technical researches, and commercialization of the results of the researches. Therefore, the company implemented a corporate knowledge management system in 2010. This knowledge management model is based on involvement of virtual (network) groups of experts.

The purpose of the network groups is to find out and efficiently use information, experience, and qualification of employees in order to enhance the production efficiency; the innovative activity management and reduction of time for the decision-making in the changing socioeconomic circumstances. The resource placed on the internal corporate platform enables on-line information exchange between structurally and geographically divided organizations of the Lukoil Group.

The experts of Lukoil have developed a nonlinear system of the numerical scoring of the company employees for new knowledge generation. Score accumulation is directly dependent on the amount and value of information entered into the system by the employees. As a result, Lukoil is able to receive new knowledge, which is of great value for the company, and define the best employees in the specific sphere.

The Bank of ideas and innovations is formed for formalization of the knowledge and allocation of the best practices.

Over 4 thousand specialists have been involved in the project. By now, the working groups have been formed and intensively work in the business segments "Downstream", "Exploration and Production", and in many other companywide areas of business.

The project has a significant economic effect provided through the cost reduction, expansion of the production capacity, and potentially prevented accidents, which are estimated by the statistic changes: for example, the total economic impact in the business segment "Oil Refining and Petrochemicals" has exceeded USD200 million since the launch of the corporate knowledge management system.

\subsection{JSC Gazpromneft}

In 2013, the Board of Directors of JSC Gazpromneft approved the program of innovative development of the company till 2020. According to the program, the knowledge management system for collection of the information on the best practices inside the company, distribution of the practices, formation of the environment for creation of new knowledge and enabling collective formation of ideas has been formed.

An e-learning portal is planned to be the platform for the formation of the culture of knowledge exchange and remote training in Gazpromneft. The portal will be involving employees into the process of development and cooperation through the base of high quality interactive courses and comfortable tools of cooperation and communication. It is planned to replace the internal social network of the company with the e-learning portal.

Gazpromneft also uses such knowledge management models as development of competence centers, i.e. structural units, which are in charge of collection and diffusion of the advanced expertise in a specific field of activity. The competence centers are developed on the base of regional structural sales units, which perform their functions more efficiently then similar services of other divisions. The competence centers of Gazpromneft accumulate and then transfer their knowledge to other divisions. Such centers receive significant authorization after passing corresponding certification: they can perform audit of the current activity and control over the business processes of other divisions, change business processes and operation methods of the services of the divisions, propose and control implementation of changes of the IT-systems, etc. The peculiarity of this model is that a specific labor team with permanent members and the common results of their activity is liable for knowledge management. In this case, revelation and duplication of the advanced experience is supplementary to the main tasks of the employees. The level of cohesion, the management style of managers, the previously formed relations with the teams of other structural units of the company, etc. have a great impact on the knowledge management efficiency.

\section{Discussion}

The performed analysis shows that the companies have carried out a significant work in the knowledge management field, managers and employees gradually rethink the term "knowledge", the formed systems of corporate knowledge 
management enable independent acquisition of knowledge by employees, quick search for required information, and experience exchange. The main conclusions on the analysis of knowledge management systems in oil companies are formulated in Table 2.

Table 2. Aggregate data on the knowledge management systems used by oil companies

\begin{tabular}{|c|l|}
\hline Company name & \multicolumn{1}{c|}{ Corporate knowledge management systems } \\
\hline JSC Tatneft & $\begin{array}{l}\text { - the IT-project "Auction of Business Ideas" is based on the crowdsourcing technology and applied for } \\
\text { generation of ideas by many persons and search for alternative solutions of problems. } \\
\text { - The "Center of the Advanced Experience" enables employees to access the joint base of knowledge } \\
\text { obtained both inside the company and during participation of the company experts in external events. }\end{array}$ \\
\hline JSC NK "Rosneft" & $\begin{array}{l}\text { The "Knowledge Management System" project is purposed for the arrangement of efficient knowledge } \\
\text { management through formalization and automation of the corresponding processes and development of } \\
\text { knowledge management methodology in the company }\end{array}$ \\
\hline JSC Lukoil & $\begin{array}{l}\text { The Knowledge Management Model based on the virtual (network) group of experts is purposed for } \\
\text { finding out and applying of the information, experience, and qualification of employees. }\end{array}$ \\
\hline JSC Gazpromneft & $\begin{array}{l}\text { Knowledge management through the development of the competence centers, i.e. structural units, which } \\
\text { are in charge of collection and diffusion of the advanced expertise in a specific field of activity. }\end{array}$ \\
\hline
\end{tabular}

The accumulated empiric knowledge requires data classification, coordination of the strategic and tactic management levels.

The corporate system of the knowledge management, which is used by the company management, is of great interest. It is not infrequent that in most cases, the best ideas are not implemented, new strategies are not fulfilled, experimental and pilot projects, which have the best effect, are not executed, and the management system is not changed. The main reason is the inertia of the intellectual modules, which have been developed and used by the company, and which are in conflict with the innovative ideas. This prevents creation of the training organizations (Senge, 2011).

Underestimation of the importance of the intellectual model is the cause of many failed efforts to implement the system approach. Even better system solutions may fail if they face established intellectual models. Thus, the intellectual models can delay training and preserve the outdated management practice.

Maybe, Royal Deutsch/Shell was the first big company, which opened the opportunities to apply intellectual models in order to accelerate the educational process. Shell managed a heavily decentralized oil company in the period of the most serious stress in the oil market in the 1970s and found out a new and unique source of the competitive advantage in the development of new intellectual models.

\section{Conclusion}

The performed studies allow for the following conclusions:

1. Unified conceptual framework and integral theory of the intellectual capital in the economics has not been formed.

2. It has been proved on the basis of the analyzed knowledge management strategies of Russian oil companies that personalization strategy is a dominant one.

3. It has been demonstrated on the basis of the empirical data that tacit knowledge, which should be transformed into explicit on the basis of special business mechanisms, dominates in the knowledge structure of modern companies.

4. It has been demonstrated in terms of research and estimation of the knowledge management practice of the biggest Russian vertically integrated oil companies that the companies have accumulated sufficient experience, which requires methodical argumentation and interpretation in order to enhance the efficiency of the intellectual capital.

5. Insufficient application of the systematic approach-based strategic management of knowledge in big oil companies has been revealed. It is related to the management thinking and requires formation and implementation of new intellectual models.

It is evident that the high scientific, technical, and human potential is accumulated by Russian oil and gas companies. Application of the knowledge management-based administrative technologies enables the stable innovative development of the company and enhancement of its efficiency and competitive ability. Application of the corporate 
knowledge management systems allow practical use of the methods, which enable maximum efficient use of the available human resources of the company.

It is planned to develop the research in the following directions:

1. estimation of the intellectual capital in oil companies on the basis of Tobin's $Q$ ratio and sharing additional revenues related to the use of mineral and raw assets;

2. development of the business mechanism of transformation of the tacit knowledge into explicit in oil companies;

3. creation and development of intracompany management of the intellectual capital in oil companies;

4. estimation of the synergistic effects in the corporate knowledge management systems;

5. improvement of the intellectual models of management in oil companies, which enable correlation between the strategic and tactic levels;

6. validation of the expert estimation methods in the crowdsourcing system.

\section{References}

APQC. Knowledge Management (KM) Program Framework. (2013). Retrieved from http://www.apqc.org/knowledge-base/collections/ apqcs-knowledge-management-program-framework .

Bontis, N. (1999). Managing organizational knowledge by diagnosing intellectual capital: framing and advancing the state of the field. International Journal of Technology Management, 18(5-8), 433-462.

Brazhnikova, Ye.N. (2012). Estimation of the efficiency of the implementation of the knowledge management system in the oil and gas companies. Moscow: Materials of the II International Conference "Optimization of the Project and Enhancement of the Efficiency of the Fuel and Energy Companies: Knowledge Management".

Brooking, E. (2001). Intellectual capital: path to success in the new millennium (pp.288). Saint Petersburg: Piter.

Daum, J.H. (2005). Intangible Assets-Based Enterprise Management - A Practical Approach. PMA IC Symposium, 15 December 2005, Stern School of Business, New York University, NYC/USA. Retrieved from http://www.juergendaum.com/news/01_15_2006.htm

Edvinsson, L., \& Malone, M. (1994). Visualizing Intellectual Capital in Scandia. Scandia.

Edvinsson, L., \& Malone, M. (1997). Intellectual Capital Realising Your Company's True Value by Finding its Hidding Brainpower. NewYork: Harper Collins.

European Guide to Good Practice in Knowledge Management. (2004). Knowledge Management Framework, Part 1. (February, 55-60). Retrieved from ftp://cenftp1.cenorm.be/PUBLIC/CWAs/e-Europe/KM/CWA14924-01-2004-Mar.pdf

Global Industry Analysis, Inc. Global Strategic Business Report. (2008). Retrieved from: http://www.strategyr.com/Knowledge Management_Market_Report.asp

McElroy, M.W. (2003). The new knowledge management: complexity, learning, and sustainable innovation. Butterworth-Heinemann.

Milner, B.Z., Rumyantseva, Z.P., Smirnova, V.G., \& Blinnikova, A.V. (2006). Corporate Knowledge Management. (Edited by Milner, B.Z., pp. 304). Moscow: Delo.

Nonaka, I., \& Takeduchi, H. (2003). Knowledge-Creating Company: How Japanese Companies Create the Dynamics of Innovation (pp. 384). Moscow: Olimp-Business.

OECD 2007. Policy brief creating value from intellectual assets. Paris: OECD, Observer.

Romer, P.M. (1995). Beyond the Knowledge. Worker Word Link. January.

Ruus, J., Pike, S., \& Fernström, L. 2008. Intellectual capital: Management Practice (pp. 448). Saint Petersburg: Publishing House of the Saint Petersburg State University.

Senge, P. (2011). The Fifth Discipline: The Art and Practice of a Learning Organization. (pp. 408). Moscow: "Olimp-Business" CJSC.

Stewart, T. (1999). Intellectual capital: The New Wealth of Organization. In New Postindustrial Wave on the West. Anthology. (Edited by Inozemtseva, V.L., pp. 372-400). Moscow: Academia.

Tuzovski, A.F., Chirikov, S.V., \& Yampolski, V.Z. (2005). Knowledge Management Systems (Methods and Technologies). (Edited by Yampolski, V.Z. pp. 260). Tomsk: NTL.

Zeghal, D. (2000). New Assets for the new Economy. FMI Journal, 11(2), 35-40.

Zeghal, D., \& Maaloul, A. (2010). Analysing value added as an indicator of intellectual capital and its consequences on company performance. Journal of Intellectual Capital, Vol. 11, 1, 39-60. 